\title{
Relationships of language learning variables in the acquisition of third languages in a multilingual context
}

\author{
Jeffrey Dawala Wilang ${ }^{1}$, Thanh Vo Duy ${ }^{2}$ \\ ${ }^{1}$ School of Foreign Languages, Institute of Social Technology, Suranaree University of Technology, Thailand \\ ${ }^{2}$ Faculty of Humanities and Social Sciences, Muban Chombueng Rajabhat University, Thailand
}

\section{Article Info \\ Article history: \\ Received Jan 18, 2021 \\ Revised Aug 3, 2021 \\ Accepted Sep 7, 2021}

\section{Keywords:}

Chinese language

Korean language

Language learning variables

Multilingual context

Third language

Vietnamese language

\begin{abstract}
This paper reinforces the importance of third language acquisition research in a multilingual context focusing on language experience, vocabulary learning strategies, emotional self-regulation strategies, and language anxiety. This study explored three languages: Chinese, Korean, and Vietnamese, to know if there are significant relationships between the above variables in third language acquisition. Three specific sets of survey questionnaires were distributed to various students enrolled in foreign language courses offered in a language department in a university. To focus on the relationships of language learning variables of a foreign language, correlational design was used to analyze the survey questionnaires' responses for each language course. Among students who were enrolled in Chinese, significant relationships were established between language anxiety and language experience, language anxiety, and emotional self-regulation strategies. Significant associations were found between emotional self-regulation strategies and language experience, emotional self-regulation strategies, and vocabulary strategies, and language performance and language experience for those students enrolled in the Korean language. In learning Vietnamese, significant relationships were found between language anxiety and vocabulary strategies, language performance, and language anxiety. Teachers may need to re-evaluate prepared teaching and learning materials, for example, material difficulty, to help students alleviate anxiety in learning.
\end{abstract}

This is an open access article under the CC BY-SA license.

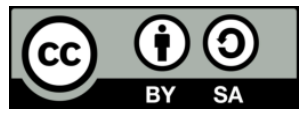

\section{Corresponding Author:}

Jeffrey Dawala Wilang

School of Foreign Languages, Institute of Social Technology

Suranaree University of Technology

111 University Avenue, Suranari, Nakhon Ratchasima 30000, Thailand

Email: wilang@g.sut.ac.th

\section{INTRODUCTION}

Multilingualism - defined as "any experience with a third language" [1] is no longer a new phenomenon, and in recent years, globalization has made it more familiar. Specifically, due to globalization, multilingualism has been given visibility and an added value concerning the ability to speak more than one language [2]. When considering an individual level, multilingualism brings together the process of learning second or foreign languages and using these languages [3]. The multilingual turn is evident in our diverse societies' communication, and it has been accommodated as an increasingly accepted feature of our communities' public life. Multilingualism exists in different spheres of ordinary living, such as in the economy, education, and personal sphere. In the present globalized world, most societies are becoming increasingly multilingual, and most people are multilingual to a certain extent. Learners in classrooms have and develop diverse language repertoires to actively construct their patterns of language use, ethnicity, and 
social identity [4]. English is still the most popular language taught in schools. However, other languages are also included in many schools' curriculum in different parts of the world, and Thailand is no exception.

In recent years, students are encouraged to become multilingual by taking third language courses such as Vietnamese, Chinese, and Korean, alongside English. These basic elective courses have been taught in the curriculum of many universities in Thailand due to the integration of the Association of Southeast Asian Nations (ASEAN). This event has made learning third languages become more crucial than ever before. To become more competitive with candidates from other nations in job hunting, Thai students should improve their third languages before graduation. According to Bagitürk and Gulmez, competence in one language is no longer sufficient. One of the general requirements to get a high-paid job is to speak additional, widely spoken languages [5]. Multilingualism can give better opportunities in job hunting, but it is also associated with identity and owned by one or more speech communities [3]. Knowledge of more than one language gives individuals more ability to acquire additional languages [6], develop more grammar learning strategies, and become better language learners [7].

However, it is observable that some people appear to be better at learning and using foreign languages than others, and the lack of learning experience may lead to plenty of difficulties in learning a third language. One would question: i) How would learners overcome these challenges?; ii) What strategies would they use in learning vocabulary?; iii) Does the use of vocabulary learning strategies have an impact on their levels of foreign language anxiety?; iv) Would their language performance also be affected? This finding has prompted the researchers to explore the phenomenon of third language learning and its impact on foreign language anxiety. A large number of studies have been conducted to investigate the impact of foreign language anxiety on bilingual learners [8]-[14]. Few research has been conducted on vocabulary learning strategies, emotional self-regulation strategies, foreign language anxiety, and language performance in learning additional or third languages.

The purpose of the present study is to determine whether there are any significant relationships among language learning experience, vocabulary strategies, emotional self-regulation strategies, language anxiety, and language performance in third language acquisition of Vietnamese, Chinese and Korean by Thai university students. One main question is answered, what are the relationships of language experience, vocabulary strategies, emotional self-regulation strategies, language anxiety, and language performance in learning a third language? Implications for teaching a third language in an EFL setting will also be discussed.

\section{PREVIOUS STUDIES}

Several language learning variables were emphasized and reviewed in the current study. It includes vocabulary learning strategies, foreign language anxiety, and emotional self-regulation strategies. These are common learning variables that impact the language learning process.

\subsection{Vocabulary learning strategies}

Over the last three decades, language learning strategies have gained much attention [15]-[18]. Strategies in language learning are defined as the techniques consciously used by language learners to remove barriers in their learning process and arrange their knowledge systematically [16], [18], [19]. According to Oxford [17], strategies can be used flexibly, independently, and appropriately.

In the context of foreign language acquisition, vocabulary learning strategies play a crucial role [20], and these strategies have been given special attention in research. Vocabulary learning strategies are a part of language learning strategies or general learning strategies [21]. According to Nation [21], there should be several vocabulary learning strategies for language learners to select from, and a strategy needs to be complicated enough that it requires many steps to learn. He also added that the use of vocabulary learning strategies requires knowledge and benefit gained from training. Of course, employing these strategies will boost the efficiency of vocabulary learning.

Several researchers have attempted to develop a taxonomy for vocabulary learning strategies. Williams [22] identified five potential learning strategies which are trainable for learners to tackle new word meaning in written texts. Those strategies infer from context, identifying lexical familiarization, unchaining nominal compounds, synonym search, and word analysis. Gu and Johnson [23] divided vocabulary learning strategies into two categories: metacognitive regulation and cognitive strategies. Their substantial list includes guessing, using a dictionary, taking notes, rehearsing, encoding, and activating.

Until 1997, Schmitt [20] developed his taxonomy based on Oxford's [17] language learning strategies, namely social, memory, cognitive, and metacognitive strategies. Schmitt classified vocabulary learning strategies into two general categories, which are discovery and consolidation strategies. Discovery strategies are strategies used by learners to discover a new word's meaning when they see the word for the first time. In contrast, consolidation strategies are the ones employed when they encounter that word again. 
According to Schmitt's [20] classification, determination (e.g., analyzing part of speech and checking for L1 cognate) and strategies are classified under discovery strategies while memory (e.g., using Loci Method and connecting the word to its synonyms or antonyms), cognitive (e.g., writing the word many times and taking notes in class) and metacognitive (e.g., reviewing the word soon after the initial meeting and continuing to study the word over time) strategies are in the category of consolidation strategies. The taxonomy consists of 58 individual strategies in total. Schmitt's taxonomy will be used as a basis for the present study because it widely covers various strategies, and it is thought to be more complete and comprehensive than any other available categorizations [24].

Needless to say, research interest in vocabulary learning strategies has received significant attention. Several research studies have been conducted to explore vocabulary learning strategy use in second language acquisition [23]-[32]. Regarding third language learning, Vo and Jaturapitakkul [33] have recently investigated the relationship between the use of vocabulary learning strategies in third language acquisition and language performance, but no significant correlation was found.

\subsection{Foreign language anxiety}

Research studies have concluded that students suffer from anxiety in foreign language learning more than in any other classes [8], [34]. Feeling nervous or worried while learning or using another tongue is unavoidable. The complexity of the foreign language learning process and the complexity of anxiety have made it difficult for researchers to define the construct of anxiety [8], [34]. According to MacIntyre and Gardner [11], foreign language anxiety refers to "the feeling of tension and apprehension specifically associated with second language contexts, including speaking, listening, and learning." A study [8] defined foreign language anxiety as "a distinct complex of self-perceptions, beliefs, feelings, and behaviors related to classroom language learning arising from the uniqueness of the language learning process."

Horwitz, Horwitz, and Cope [8] determined several factors that contributed to the foreign language classroom anxiety. They theorized that foreign language anxiety is linked to performance anxiety, including communication apprehension - fear of or anxiety about communicating with people; test anxiety - fear of failure; and fear of negative evaluation - apprehension about others' negative evaluations. The Foreign Language Classroom Anxiety Scale (FLCAS) was developed in accordance with these types of anxiety to measure anxiety in the foreign language classroom.

Foreign language anxiety (FLA) could be an affective factor that severely obstructs the acquisition of the second or foreign language [35]-[37] and language performance [38]-[41]. Several investigations have indicated that FLA has debilitative effects on many aspects of language learning, for example, listening [42], [43], speaking [44]-[46], writing [47], [48], reading [49], [50]. Other research exploring the association between foreign language anxiety and language performance has revealed that foreign language anxiety also negatively affects learners' achievement [9], [51]. In other words, the higher the learners' anxiety levels are, the lower their scores will be, and vice versa. Similarly, some studies revealed that language anxiety could be one of the best predictors of learners' language performance [52]-[55]. However, Marcos-Llinás and Garau [56] found no significant effect on learners' academic success.

\subsection{Emotional self-regulation strategies}

Generally, affective strategy (emotion-related) can be one of the factors to be considered most for foreign language learning and teaching. This type of strategy refers to emotion, feelings, mood, manner, and attitudes [57], [58]. Guo and Wang argued that these factors could be an emotional part of the human language learning system [59]. Oxford and Scarcella [60] described affective strategy as a direct strategy employed by learners to improve their language performance. Oxford [17] developed Strategy Inventory for Language Learning (SILL) to measure the frequency of language learning strategies, including affective strategies.

Research has shown that affective strategies were significantly related to learners' proficiency [61], [62]. Recently, affective strategies have positively correlated with learners' anxiety levels [63], [64]. However, in Mullins' study [65], a negative correlation between affective strategies and some learners' proficiency measures has been established.

In the present study, Oxford's affective strategies [17], hereinafter referred to as emotional selfregulation strategies, were employed to measure students' strategy use in third language acquisition context. These strategies refer to identifying one's mood and anxiety level, talking about feelings, rewarding oneself for good performance, and using deep breathing or positive self-talk. 


\section{RESEARCH METHOD}

\subsection{Research setting}

The research was conducted at a university in Bangkok, Thailand. Alongside English, a compulsory course, students are encouraged to enroll in an elective third language course such as Chinese, Korean, and Vietnamese. The number of instructional hours for each course is 45 hours, and English is a medium of instruction. Students had limited prior experience in learning these third languages.

\subsection{Chinese language course and participants}

The Chinese language course is an introduction to a Modern Mandarin Chinese course that aims to train students to practice Mandarin Chinese with phonetics and tones. Focusing on standard Beijing pronunciation, alphabets, and vowels, students are expected to use Mandarin Chinese for communication in daily life, such as greeting, making introductions, expressing likes and dislikes, expressing wants and needs, and saying goodbye. There were 53 students taking this course had participated in the present study.

\subsection{Korean language course and participants}

The Korean language course focuses on sound systems and alphabets. It involves basic communication skills in everyday situations, for example, greeting and introducing oneself, giving information about people in the family, telling dates and time, explaining free time activities and interests, ordering food, asking questions about prices, shopping, as well as giving information about places, locations, and directions. The number of participants from this group was 50 .

\subsection{Vietnamese language course and participants}

The Vietnamese language course is an elementary course aiming to introduce basic knowledge of Vietnamese. Students will learn how to speak daily Vietnamese in some everyday situations such as greeting for the first time, introducing themselves, ordering foods, and so on. Students will also learn some grammar points at the beginning level. Additionally, students will know more about Vietnamese culture and the Vietnamese people. Only 50 participated willingly in the present study.

\subsection{Instruments}

A survey questionnaire was utilized to collect the data about the participants' language experience as well as vocabulary strategies, emotional self-regulation strategies, and language anxiety. The vocabulary strategies were measured using the Vocabulary Learning Strategies Questionnaire (VLSQ) developed by Schmitt [20]. It consists of 39 statements with a 5-point Likert scale. Five factors were included, such as determination strategies, social strategies, memory strategies, cognitive strategies, and metacognitive strategies. The emotional self-regulation strategies were measured by eliciting six items from Oxford [17]. It focuses on regulating their emotions when they are afraid of using the third language, when they are afraid of making mistakes, performing well, and when they are nervous while studying. The language anxiety was measured using FLCAS developed by Horwitz, Horwitz, and Cope [8]. It consists of 33 statements with a 5-point Likert scale. The factors were included, such as communication apprehension, fear of negative evaluation, and test anxiety. Several studies have indicated the instrument's high reliability [8], [66]-[68]. The language performance is the total score each student received at the end of the semester.

\subsection{Data collection procedures}

After the researchers had explained the purpose of the research, a consent form attached with the self-report anxiety survey, the vocabulary learning strategy, and the emotional self-regulation strategy questionnaire was administered during class at the beginning of the second semester in April 2018. At the end of the semester, the total scores were also collected from the teachers of the three language courses. All students were informed that their participation does not affect their final grades.

\subsection{Data analysis}

SPSS was used to compute mean scores and establish the relationships between various variables such as language experience, vocabulary strategies, emotional self-regulation strategies, language anxiety, and language performance. To compute mean score and standard deviation, descriptive statistics was used. To calculate statistical relationships, correlational statistics was utilized. 


\section{RESULTS}

\subsection{Chinese language course}

Table 1 denotes significant relationships between language anxiety and language experience, language performance and language experience, and language anxiety and emotional self-regulation strategies. The relationships indicate the following: the more experience Chinese language learners have, the higher their language anxiety becomes, Chinese language learners receive lower grades when they have lower years of language experience, and the higher their anxiety in learning Chinese, the more emotional self-regulation they use.

In Table 1, findings indicate a significant role played by language anxiety among learners of Chinese as a third language. For instance, anxiety increases as they gain more experiences. This could be explained by the desired learning outcomes, of which students are expected to communicate about daily life, from simpler to more difficult communicative tasks. However, the findings cannot establish whether anxiety in this context has a debilitating or facilitating effect compared to previous studies in EFL or ESL settings. In this study, it can be noted more emotional self-regulation strategies were used when learners experienced a higher level of anxiety.

Table 1. Descriptive statistics and correlations among Chinese language learners

\begin{tabular}{lccccccc}
\hline \multicolumn{1}{c}{ Variable } & Mean & SD & 1 & 2 & 3 & 4 & 5 \\
\hline 1. Language experience & 1.28 & 0.45 & - & & & & \\
2. Vocabulary strategies & 130.94 & 20.75 & 0.08 & - & & & \\
3. Emotional self-regulation strategies & 17.20 & 4.17 & .23 & 0.24 & - & & \\
4. Language anxiety & 95.01 & 14.56 & $.33^{*}$ & 0.25 & $0.49^{* *}$ & - & \\
5. Language performance & 84.92 & 10.03 & $0.05^{*}$ & 0.12 & -0.02 & 0.09 & - \\
\hline
\end{tabular}

Note: ${ }^{*} \mathrm{p}<0.05,{ }^{* *} \mathrm{p}<0.01$

\subsection{Korean language course}

Table 2 indicates significant relationships between emotional self-regulation strategies and language experience, emotional self-regulation strategies, and vocabulary strategies, and language performance and language experience. This means Korean language learners use lesser emotional self-regulation strategies as they gain more language experiences; when Korean language learners regulate their emotions, the more they can use vocabulary strategies; and the lesser experience Korean language learners have, the lower their grades become. Table 2 indicates a significant role played by emotional self-regulation strategies in vocabulary learning.

Table 2. Descriptive statistics and correlations among Korean language learners

\begin{tabular}{lccccccc}
\hline \multicolumn{1}{c}{ Variable } & Mean & SD & 1 & 2 & 3 & 4 & 5 \\
\hline 1. Language experience & 1.44 & 0.50 & - & & & & \\
2. Vocabulary strategies & 134.44 & 18.11 & 0.11 & - & & & \\
3. Emotional self-regulation strategies & 17.40 & 4.73 & $0.39^{* *}$ & $0.52^{* *}$ & - & & \\
4. Language anxiety & 93.74 & 11.39 & 0.25 & 0.06 & -0.03 & - & \\
5. Language performance & 78.10 & 12.29 & $-0.31 *$ & 0.06 & -0.13 & -0.25 & - \\
\hline
\end{tabular}

Note: $* \mathrm{p}<0.05, * * \mathrm{p}<0.01$

\subsection{Vietnamese language course}

Table 3 shows significant relationships between language anxiety and vocabulary strategies and language performance and language anxiety. The relationships mean that the higher anxiety Vietnamese language learners have, the more they use vocabulary strategies. Vietnamese language learners get lower grades when they experience more elevated anxiety levels. Table 3 indicates a significant role played by language anxiety in language performance. Like previous studies reported in EFL settings, anxiety has a debilitative role in learning the Vietnamese language.

Table 3. Descriptive statistics and correlations among Vietnamese language learners

\begin{tabular}{lccccccc}
\hline \multicolumn{1}{c}{ Variable } & Mean & SD & 1 & 2 & 3 & 4 & 5 \\
\hline 1. Language experience & 1.79 & 0.40 & - & & & & \\
2. Vocabulary strategies & 140.74 & 19.67 & 0.25 & - & & & \\
3. Emotional self-regulation strategies & 17.82 & 4.01 & -0.16 & -0.22 & - & & \\
4. Language anxiety & 89.20 & 10.89 & 0.08 & $0.43^{* *}$ & 0.05 & - & \\
5. Language performance & 83.05 & 7.02 & -0.07 & 0.07 & 0.00 & $-0.39^{*}$ & - \\
\hline Note: $* \mathrm{p}<0.05, * * \mathrm{p}<0.01$ & & & & & & &
\end{tabular}




\section{DISCUSSION}

It is essential to highlight and discuss the following results. In learning the Chinese language, emotional self-regulation strategies are crucial in managing learner anxiety toward the language. Similar to previous findings [63], [64], this study shows a positive correlation between language anxiety and emotional self-regulation strategies. Therefore, to help learners, equipping them with emotional self-regulation strategies would be beneficial so that they would be able to manage their negative emotions in third language acquisition, in this case, high anxiety. Oxford's [17] recommended some strategies, including positive actions toward self, deep breathing, and even talking about others' negative feelings.

Another interesting finding concerns the positive association between emotional self-regulation strategies and vocabulary strategies in learning Korean as a third language. This means that when learners have the 'right' feelings in language learning, they can use specific language strategies to learn vocabularies. For example, when encountering a new word, learners with low anxiety may use discovery strategies [27], such as asking their teacher or friends to know the meaning of the word. On the other hand, learners with high anxiety upon seeing the new word may not dare to ask the meaning aloud, not to lose face in class.

In learning a third language, it is interesting to note that anxiety could be detrimental and has a debilitating effect on language performance, as in the case of Vietnamese language learners. This finding affirms the negative impact of anxiety on language performance [33], [38], [41]. The high anxiety feelings may arise from the nature of the course where learners are expected to communicate in Vietnamese when they greet and introduce themselves, among others. Although the language functions above are basic, the participants in this study are also enrolled in learning English, another anxiety-provoking course among students [8], [43], [50].

\section{CONCLUSION}

Using multiple case studies, this study explored the significant relationships of several language learning variables in acquiring a third language (i.e., Chinese, Korean, and Vietnamese) in a multilingual context. Although the results are inconclusive across learning all third languages, the results from the case studies highlight the use of emotional self-regulation strategies, the need to reduce language anxiety, and the learners' exposure to the target language. It is to help them reach their goals in learning a third language.

At the beginning of the course, teachers may consider conducting a quick survey concerning learner attitude, feelings, knowledge, and strategies toward a third language. This would help teachers design a more personalized method for dealing with learning difficulties, such as high anxiety. If teachers know that learners are anxious about learning a specific language, teaching emotional self-regulation strategies would be necessary to deal with anxiety-provoking situations in learning. Not only that, teachers may need to reevaluate prepared teaching and learning materials, for example, material difficulty, to help students alleviate anxiety in learning.

\section{REFERENCES}

[1] A.S. Thompson and A.J. Khawaja, "Foreign language anxiety in Turkey: the role of multilingualism," Journal of Multilingual and Multicultural Development, vol. 37, no. 2, pp. 115-130, 2016.

[2] V. Edwards, Multilingualism in the English-Speaking World. Oxford: Blackwell, 2004.

[3] J. Cenoz and D. Gorter, "Focus on multilingualism as an approach in educational contexts," in A. Creese and A. Blackledge, eds., Heteroglossia as Practice and Pedagogy. Berlin: Springer, 2014, pp. 239-254.

[4] W. Leung, A. Malkova and J.E. Haber, "Gene targeting by linear duplex DNA frequently occurs by assimilation of a single strand subject to preferential mismatch correction," Proc Natl Acad Sci U S A., vol. 94, no. 13, pp. 6851-6856, 1997.

[5] M. Bagtürk and R. Gulmez, "Multilingual learning environment in French and German language teaching departments," The Online Journal of New Horizons in Education, vol. 1, no. 2, pp. 16-22, 2011.

[6] J. Dewaele, K.V. Petrides and A. Furnham, "The effects of trait emotional intelligence and sociobiographical variables on communicative anxiety and foreign language anxiety among adult multilinguals: A review and empirical investigation," Language Learning, vol. 58, no. 4, pp. 911-960, 2008.

[7] C. Kemp, "Metalinguistic awareness in multilinguals: Implicit and explicit grammatical awareness and its relationship with language experience and language attainment," Unpublished $\mathrm{PhD}$ Thesis, University of Edinburgh, 2001.

[8] E.K. Horwitz, M.B. Horwitz, and J. Cope, "Foreign language classroom anxiety," The Modern Language Journal, vol. 70, no. 2, pp. 125-32, 1986.

[9] D.J. Young, "Creating a low-anxiety classroom environment: What does language anxiety research suggest?" The Modern Language Journal, vol. 75, no. 4, pp. 426-439, 1991.

[10] K. Ohata, "Language anxiety from the teacher's perspective: interviews with seven experienced ESL/EFL teachers," Language Learning Journal, vol. 3, no. 1, pp. 1-21, 2005. 
[11] P. MacIntyre and R. Gardner, "Methods and results in the study of anxiety and language learning: A review of literature," Language Learning, vol. 41, no. 1, p. 284, 1991.

[12] R. Zhang and J. Zhong, "The hindrance of doubt: causes of language anxiety," International Journal of English Linguistics, vol. 2, no. 3, pp. 27-33, 2012.

[13] F. Alrabai, "A model of foreign language anxiety in the Saudi EFL context," English Language Teaching, vol. 7, no. 7, pp. 82-101, 2014.

[14] M.A. Alshahrani, 'The level of anxiety on the achievement of the Saudi EFL learners," Arab World English Journal (AWEJ), vol. 7, no. 3, pp. 65-76, 2016.

[15] A. Chamot, "The Learning Strategies of ESL Students," In A. Wenden and J. Rubin, Eds., Learner Strategy in Language Learning. Englewood Cliffs, NJ: Prentice Hall, Inc., 1987, pp. 71-83.

[16] J.M. O'Malley and A.U. Chamot, Learning strategies in Second Language Acquisition. Cambridge: Cambridge University Press, 1990.

[17] R.L. Oxford, Language Learning Strategies: What every teacher should know. New York: Newbury House, 1990.

[18] A.D. Cohen, Strategies in Learning and Using a Second Language. Addison Wesley Longman Limited, 1998.

[19] S.H. McDonough, "Learner strategies," Language Teaching, vol. 32, no. 1, pp. 1-18, 1999.

[20] N. Schmitt, "Vocabulary learning strategies," In N. Schmitt and McCarthy, Eds., Vocabulary: description, acquisition and pedagogy. Cambridge: Cambridge University Press, 1997, pp. 199-228.

[21] I.S. Nation, Learning Vocabulary in Another Language. Cambridge: Cambridge University Press, 2001

[22] R. Williams, Keywords: a vocabulary of culture and society. New York: Oxford University Press, 1985.

[23] Y. Gu and R.K. Johnson, "Vocabulary learning strategies and language learning outcomes," Language Learning, vol. 46, no. 4, pp. 643-679, 1996.

[24] M. Yazdi and R. Kafipour, "A qualitative study of vocabulary learning strategies applied by Iranian undergraduate learners in real learning setting," English Language Teaching, vol. 7, no. 7, pp. 1-7, 2014.

[25] P.C.H. Lip, "Investigating the most frequently used and most useful vocabulary language learning strategies among Chinese EFL postsecondary students in Hong Kong," Electronic Journal of Foreign Language Teaching, vol. 6, no. 1, pp. 77-87, 2009.

[26] S. Wanpen, K. Sonkoontod and K. Nonkukhetkhong, "Technical vocabulary proficiencies and vocabulary learning strategies of engineering students," Procedia - Social and Behavioral Sciences, vol. 88, pp. 312-321, 2013.

[27] N. Schmitt, Vocabulary in language teaching. New York: Cambridge University Press, 2000.

[28] T. Alharthi, "Role of vocabulary learning strategies in EFL learners' word attrition," International Journal of English Language and Linguistics Research, vol. 2, no. 3, pp. 13-28, 2014.

[29] A. Sánchez and M.R. Manchón, "Research on second language vocabulary acquisition and learning: An introduction," International Journal of English Studies, vol. 7, no. 2, pp. vii-xvi, 2007.

[30] A. Asgari and B.G. Mustapha, "The type of vocabulary learning strategies used by ESL students in University Putra Malaysia," English Language Teaching, vol. 4, no. 2, pp. 84-90, 2011.

[31] M. Nosratinia, M. Saveiy, and A. Zaker, "EFL learners' self-efficacy, metacognitive awareness, and use of language learning strategies: how are they associated?" Theory and Practice in Language Studies, vol. 4, no. 5, pp. 1080-1092, 2013.

[32] S. Zarrin and Z. Khan, "A study of vocabulary learning strategies among undergraduate learners of A.M.U," USChina Foreign Language, vol. 12, no. 1, pp. 75-82, 2014.

[33] D.T. Vo and N. Jaturapitakkul, "The use of vocabulary learning strategies by Thai EFL learners studying Vietnamese as a third language," Language Education and Acquisition Research Network (LEARN) Journal, vol. 9, no. 2, pp. 105-121, 2016.

[34] P.D. MacIntyre, and R.C. Gardner, "The subtle effects of language anxiety on cognitive processing in the second language," Language Learning, vol. 44, no. 2, pp. 283-305, 1994.

[35] J. Arnold, “Attention to affect in language learning," Anglistik International Journal of English Studies, vol. 22, no. 1, pp. 11-22, 2011.

[36] D.H. Brown, "A map of the terrain," J. Arnold, Ed., Affect in Language Learning. Cambridge: Cambridge University Press, 1999, pp. 1-24.

[37] L. Hu and N. Wang, "Anxiety in foreign language learning," Proceedings of the 2014 International Conference on Global Economy, Commerce and Service Science, Phuket, Thailand, vol. 78, 2014, pp. 122-124.

[38] M. Liu and J. Jackson, "An exploration of Chinese EFL learners' unwillingness to communicate and foreign language anxiety,” The Modern Language Journal, vol. 92, no. 1, pp. 71-86, 2008.

[39] E.K. Horwitz, "Foreign and second language anxiety," Language Teaching, vol. 43, no. 2, pp. 154-167, 2010.

[40] P.D. MacIntyre and T. Gregersen, "Emotions that facilitate language learning: The positive-broadening power of the imagination," Studies in Second Language Learning and Teaching, vol. 2, no. 2, pp. 193-213, 2012.

[41] C. Gkonou, M. Daubney, and M.J. Dewaele, New Insights into Language Anxiety: Theory, Research and Educational Implications. Multilingual Matters, 2017.

[42] M.M. Golchi, "Listening anxiety and its relationship with listening strategy use and listening comprehension among Iranian IELTS learners," International Journal of English Linguistics, vol. 2, no. 4, pp. 115-128, 2012.

[43] H. Elkhafaifi, "Listening comprehension and anxiety in the Arabic language," The Modern Language Journal, vol. 89, no. 2, pp. 206-220, 2005.

[44] E.M. Phillips, "The effects of language anxiety on students oral test performance and attitudes," The Modern Language Journal, vol. 76, no. 1, pp. 14-26, 1992.

[45] H. Park and A.R. Lee, "L2 learners' anxiety, self-confidence and oral performance," The 10th Conference of PanPacific Association of Applied Linguistics, Edinburgh University, 2005, pp. 197-208. 
[46] Z. Suleimenova, "Speaking anxiety in a foreign language classroom in Kazakhstan," Procedia - Social and Behavioral Sciences, vol. 93, pp. 1860-1868, 2013.

[47] Z. Susoy and S. Tanyer, "A closer look at the foreign writing anxiety of Turkish EFL pre-service teachers," Proceedings of IAC-ETel 2013, Prague, Czech Republic, 2013.

[48] I.K. Tsiriotakis, E. Vassilaki, I. Spantidakis, and NAM. Stavrou, "The examination of the effects of writing strategy-based procedural facilitative environments on students' English foreign language writing anxiety levels," Frontiers in Psychology, vol. 7, no. 2074, pp. 1-14, 2017.

[49] A. Zhao, J. Dynia and Y. Guo, "Foreign language reading anxiety: Chinese as a foreign language in the United States," The Modern Language Journal, vol. 97, no. 3, pp. 1-15, 2013.

[50] H. Zhang and Y. Kim, "Foreign language reading anxiety: Chinese learners of Korean," Studies in Linguistics, vol. 32, pp. 21-45, 2014.

[51] E. Bensalem, "Foreign language learning anxiety: the case of trilinguals," Arab World English Journal (AWEJ), vol. 8, no. 1, pp. 234-249, 2017.

[52] Y. Aida, "Examination of Horwitz, Horwitz, and Cope's construct of foreign language anxiety: The case of students of Japanese," The Modern Language Journal, vol, 78, no. 2, pp. 155-168, 1994.

[53] J.D. Wilang and T.D. Vo, "The complexity of speaking anxiety in a graduate EFL classroom," The Journal of Asia TEFL, vol. 15, no. 3, pp. 682-699, 2018.

[54] Y. Saito and K.K. Samimy, "Foreign language anxiety and language performance: A study of learner anxiety in beginning, intermediate, and advanced-level college students of Japanese," Foreign Language Annals, vol. 29, no. 2, pp. 239-251, 1996.

[55] A.J. Onwuegbuzie, J. Slate, F. Paterson, M. Watson, and R. Schwartz, "Factors associated with underachievement in educational research courses," Research in the Schools, vol. 7, no. 1, pp. 53-65, 2000.

[56] M. Marcos-Llinás and M.J. Garau, "Effects of language anxiety on three proficiency-level courses of Spanish as a foreign language," Foreign Language Annals, vol. 42, no. 1, pp. 94-111, 2009.

[57] H. Ni, "The effects of affective factors in SLA and pedagogical implications," Theory and Practice in Language Studies, vol. 2, no. 7, pp. 1508-1513, 2012.

[58] M. Khameis, "Using Creative Strategies to Promote Students' Speaking Skills," 2021. [Online]. Available: https://www.academia.edu/6773480/07_Using_Creative_Strategies_to_Promote_Students_Speaking_Skills.

[59] M. Guo and Y. Wang, "Affective factors in oral English teaching and learning," Higher Education of Social Science, vol. 5, no. 2, pp. 57-61, 2013.

[60] R.L. Oxford and R.C. Scarcella, "Second language vocabulary learning among adults: state of the art in vocabulary instruction," System, vol. 22, no. 2, pp. 231-243, 1994.

[61] C. Dreyer and R. Oxford, "Learning strategies and other predictors of ESL proficiency among Afrikaans-speakers in South Africa," In R. Oxford, Ed., Language Learning Strategies Around the World: Cross-cultural Perspectives. Manoa: University of Hawaii Press, 1996, pp. 61-74.

[62] M.E. Ehrman and R.L. Oxford, "Cognition Plus: Correlates of Language Learning Success," Modern Language Journal, vol. 79, no. 1, pp. 67-89, 1995.

[63] A.M. Galti, "Awareness of students' on the use of affective strategy and their level of speaking anxiety," International Journal of Multidisciplinary Research and Development, vol. 3, no. 3, pp. 319-322, 2016.

[64] A.M. Galti and Z. Tahiru, "Correlation between use of affective strategy and speaking anxiety among ShehuGarbai secondary school students in Maiduguri-Borno state," Indian Journal of Innovations and Developments, vol. 5, no. 12, pp. 1-5, 2016.

[65] P.Y. Mullins, "Successful English language learning strategies of students enrolled at the Faculty of Arts, Chulalongkorn University, Bangkok, Thailand," Doctoral Dissertation, United States International University, 1992.

[66] R. Awan, M. Azher, M.N. Anwar, and A. Naz, "An investigation of foreign language classroom anxiety and its relationship with students achievement," Journal of College Teaching \& Learning (TLC), vol. 7, no. 11, pp. 33-40, 2010.

[67] Ö. Demirdaş and D. Bozdoğan, "Foreign language anxiety and performance of language learners in preparatory classes," Turkish Journal of Education, vol. 2, no. 3, pp. 4-13, 2013.

[68] T.D. Vo, V. Samoilova and J.D. Wilang, "Debilitating effects of anxiety on engineering students' language performances," Proceedings of the 3rd International Conference on Innovation in Education, Thailand: Institute for Innovative Learning, Mahidol University, vol. 3, 2017, pp. 275-285. 